\title{
Inspiratory Valve Device
}

National Cancer Institute

\section{Source}

National Cancer Institute. Inspiratory Valve Device. NCI Thesaurus. Code C50252.

A valve designed to regulate the flow of gases into a respirator or respiration system. 